\title{
The Use of C-Reactive Protein (CRP) as a Marker of the Surgical Stress in Gastrointestinal Surgery
}

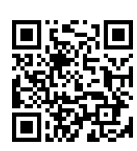

\author{
Ana Belén Martínez Martínez* \\ Faculty of Health Sciences, University of Zaragoza, Spain
}

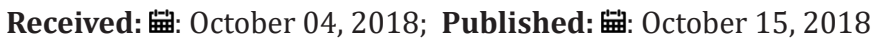

*Corresponding author: Ana Belén Martínez Martínez, Faculty of Health Sciences, University of Zaragoza, Zaragoza, Spain

\begin{abstract}
Being able to predict the complications that can arise after a surgical intervention is essential to accelerate the recovery of patients, minimize pain or save their lives in the most crucial cases. Different markers of surgical aggression [1-3] have been studied, being to use C-reactive protein (CRP) measurement during the postoperative period the current trend to predict the evolution of the patients [4-6]. A brief review of the utility of CRP measurement is showed to assess its use as the choice marker of the surgical injury.
\end{abstract}

Keywords: CRP; Gastrointestinal surgery; Inflammation marker; Surgical injury

Abbreviations: CRP: C-Reactive Protein; SIRS: Systemic Inflammatory Response Syndrome; OS: Open Surgery; LS: Laparoscopic Surgery; WBC: White Blood Cells

\section{Introduction}

After surgery, it is necessary to establish a series of markers that tell us the patient prognosis and allow a prompt action whether it is not favourable. CRP is a tissue aggression marker. Multiple studies incorporate it to see the immune response of the patients after the surgical aggression and then study the degree of inflammatory response (7-10). The higher its value, the higher the probability of systemic inflammatory response syndrome (SIRS). CRP measurement is done just before surgery and in the postoperative days to see its evolution. Whether its values increase with time, it is indicative of a greater inflammatory response, and therefore, of a possible complication during recovery.

\section{Open Surgery and Laparoscopic Surgery}

Within the gastrointestinal surgery there are two fundamental surgical procedures, open surgery (OS) and laparoscopic surgery (LS). Although evidence-based medicine shows that the laparoscopic approach is more beneficial for the patient and its recovery [1113], there are still some doubts about its use since discrepancies have been obtained in studies to observe the immune response of patients [14-16], especially in certain surgical resections or when their performance cannot be carried out by properly trained surgeons. CRP is the usual marker used among others to compare both surgical approaches and justify that approach produces a lower inflammatory response, and therefore would be the most beneficial for the patient recovery. Most studies indicate lower values of CRP in LS compared to OS in the postoperative days [1720]. Few studies find no significant differences between OS and LS groups [21,22], characterized by having a low number of study subjects or because the clinical and surgical characteristics (body mass index, duration of surgery, blood loss) have differed between the two comparison groups. These facts would indicate that CRP is a good marker of the inflammatory response, since its value increases taking into account all the factors of study and is not only affected by the surgical approach. In fact, several studies have observed there are no significant differences in CRP values when comparing OS and LS in patients who have suffered complications [4], even comparing patients included in ERAS protocols versus standard care protocols [6].

\section{Complications and ERAS Protocols}

CRP use as an early complications marker is increasingly widespread. CRP levels rise after the surgical act observing a peak at $48 \mathrm{~h}$, after which time its values decrease in patients who do not suffer complications. In this way, it is used as a discharge criterion whether the elevation of its values is not observed throughout the postoperative period [23]. In addition, CRP measurement is a good candidate to observe which ERAS parameters have more influence on the recovery of the patient. Since the application of these protocols, countless benefits have been reported [24]. However, its implementation is complex and requires great coordination among 
all the health personnel involved. Measures to take through the CRP marker assessment, reducing them to the minimum necessary, could help to extend ERAS protocols implementation.

\section{Other Markers}

Other markers have been studied for the degree of inflammatory response after the surgical act [25]. In addition to CRP, the main inflammatory markers studied have been IL-6, cortisol and white blood cells (WBC) count [26]. IL-6 seems to show similar results to CRP $[15,27]$. Furthermore, the time of peak response is earlier than CRP, between 12 and 24 hours. However, its measurement is not within clinical routine laboratory worldwide, being its use less widespread. Regarding cortisol, it has been reported an early time of peak response, from 0 to 4 hours. However, cortisol concentrations have not been associated clearly with the magnitude of the surgical injury [28]. The same happens with the WBC. In spite of detecting its response peak before than CRP, at 24 hours, the variable range of values obtained does not allow to assess the magnitude of the surgical damage and, therefore, of the inflammatory response and the possibility of SIRS [29]. Other studies have made measurements of parameters such as alarmines, serum cytokines, alpha defensins and TNF- $\triangle$ among others in the search for a more specific marker [21,30-32]. However, their measurements are more complex and the results obtained do not provide much additional information. CRP values increase according to the magnitude of the surgical trauma, its measurement is simple and is established as routine in most hospitals, being therefore the marker usually chosen.

\section{CRP in the Future}

In general, CRP seems to be a good marker of the inflammatory response and its use is increasingly widespread. However, there are several disadvantages in its use. On the one hand, it is a nonspecific inflammatory marker. It would be necessary to work in the search of more specific or complementary markers that would orient on the type of complication to appear, or at least, on the degree of complication according to the Clavien Dindo complications scale. On the other hand, until roughly 48 hours CRP peak response cannot be clearly detected, being usual to observe high values up to 4 days later. Thus, reaction time before a serious complication is reduced. A marker that indicated earlier the beginning of a complication would be more appropriate. And finally, there is still no standardization on its use. The times in which CRP measurements are made depend on the organizational structure of each hospital. In general, measurements are made between prior to surgery and 72 hours post-surgery, being variable the number and times of measurement. Most studies perform CRP measurements preoperatively and in the first, second and third postoperative day. Working on a standardization of its use and the establishment of alarm reference values should be a priority task to be used as an early marker of surgical complications and as an indicator of a lesser inflammatory process when comparing different techniques or procedures.

\section{References}

1. Huang C, Huang R, Jiang T, Huang K, Cao J, et al. (2010) Laparoscopic and open resection for colorectal cancer: an evaluation of cellular immunity. BMC Gastroenterol 10: 127.
2. Veenhof AA, Sietses C, Von Blomberg BM, van Hoogstraten IM, Vd Pas MH, et al. (2011) The surgical stress response and postoperative immune function after laparoscopic or conventional total mesorectal excision in rectal cancer: a randomized trial. Int J Colorectal Dis 26(1): 53-59.

3. Decker D, Schondorf M, Bidlingmaier F, Hirner A, Von Ruecker AA (1996) Surgical stress induces a shift in the type-1/type-2 T-helper cell balance, suggesting downregulation of cell-mediated and up-regulation of antibody-mediated immunity commensurate to the trauma. Surgery 119(3): 316-325.

4. Straatman J, Cuesta MA, Tuynman JB, Veenhof AAFA, Bemelman WA, et al. (2018) C-reactive protein in predicting major postoperative complications are there differences in open and minimally invasive colorectal surgery? Substudy from a randomized clinical trial. Surg Endosc 32(6): 2877-2885.

5. Dutta S, Fullarton GM, Forshaw MJ, Horgan PG, McMillan DC (2011) Persistent elevation of C-reactive protein following esophagogastric cancer resection as a predictor of postoperative surgical site infectious complications. World J Surg 35(5): 1017-1025.

6. Cabellos Olivares M, Labalde Martínez M, Torralba M, Rodríguez Fraile JR, Atance Martínez JC (2018) C-reactive protein as a marker of the surgical stress reduction within an ERAS protocol (Enhanced Recovery After Surgery) in colorectal surgery: A prospective cohort study. J Surg Oncol 117(4): 717-724.

7. Gustafsson UO, Tiefenthal M, Thorell A, Ljungqvist O, Nygrens J (2012) Laparoscopicassisted and open high anterior resection within an ERAS protocol. World J Surg 36(5): 1154-1161.

8. Braga M, Vignali A, Zuliani W, Radaelli G, Gianotti L, et al. (2002) Metabolic and functional results after laparoscopic colorectal surgery: a randomized, controlled trial. Dis Colon Rectum 45(8): 1070-1077.

9. Delgado S, Lacy AM, Filella X, Castells A, García Valdecasas JC, et al. (2001) Acute phase response in laparoscopic and open colectomy in colon cancer: randomized study. Dis Colon Rectum 44(5): 638-646.

10. Dunker MS, Ten Hove T, Bemelman WA, Slors JF, Gouma DJ, et al. (2003) Interleukin-6, C-reactive protein, and expression of human leukocyte antigen-DR on peripheral blood mononuclear cells in patients after laparoscopic vs. conventional bowel resection: a randomized study. Dis Colon Rectum 46(9): 1238-1244.

11. Bärlehner E, Benhidjeb T, Anders S (2004) Laparoscopic surgery for colon and rectal cancer. Surg Technol Int 13: 93-99.

12. Hasegawa H, Kabeshima Y, Watanabe M, Yamamoto S, Kitajima M (2003) Randomized controlled trial of laparoscopic versus open colectomy for advanced colorectal cancer. Surg Endosc 17(4): 636-640.

13. Nelson H, Sargent DJ, Wieand HS, Fleshman J, Anvari M, et al. (2004) The Clinical Outcomes of Surgical Therapy Study Group. A comparison of laparoscopically assisted and open colectomy for colon cancer. N Engl J Med 350(20): 2050-2059.

14. Ozawa A, Konishi F, Nagai H, Okada M, Kanazawa K (2003) Cytokine and hormonal responses in laparoscopic-assisted colectomy and conventional open colectomy. Surg Today 30(2): 107-111.

15. Tsamis D, Theodoropoulos G, Stamopoulos P (2012) Systemic inflammatory response after laparoscopic and conventional colectomy for cancer: a matched case-control study. Surg Endosc 26(5): 1436-1443.

16. Han SA, Lee WY, Park CM (2010) Comparison of immunologic outcomes of laparoscopic vs open approaches in clinical stage III colorectal cancer. Int J Colorectal Dis 25: 631-638.

17. Ramanathan ML, MacKay G, Platt J, Horgan PG, McMillan DC (2015) The impact of open versus laparoscopic resection for colon cancer on C-reactive protein concentrations as a predictor of postoperative infective complications. Ann Surg Oncol 22(3): 938-943.

18. Schwenk W, Haase O, Neudecker J, Muller JM (2005) Short term benefits for laparoscopic colorectal resection. Cochrane Database Syst Rev 20(3): CD003145. 
19. Wang G, Jiang Z, Zhao K, Li G, Liu F, et al. ( 2012) Immunologic response after laparoscopic colon cancer operation within an enhanced recovery program. J Gastrointest Surg 16(7): 1379-1388.

20. Ng SS, Leung KL, Lee JF, Yiu RY, Li JC, et al. (2009) Long-term morbidity and oncologic outcomes of laparoscopic-assisted anterior resection for upper rectal cancer: ten-year results of a prospective, randomized trial. Dis Colon Rectum 52(4): 558-566.

21. Máca J, Peteja M, Reimer P, Jor O, Šeděnková V, et al. (2018) Surgical injury: comparing open surgery and laparoscopy by markers of tissue damage. Ther Clin Risk Manag 30(14): 999-1006.

22. Wu FP, Sietses C, von Blomberg BM, van Leeuwen PA, Meijer S, et al. (2003) Systemic and peritoneal inflammatory response after laparoscopic or conventional colon resection in cancer patients: a prospective, randomized trial. Dis Colon Rectum 46(2): 147-155.

23. Straatman J, Cuesta MA, Gisbertz SS, Van der Peet DL (2014) Value of a step-up diagnosis plan: CRP and CT-scan to diagnose and manage postoperative complications after major abdominal surgery. Rev Esp Enferm Dig 106(8): 515-521.

24. Khan SA, Ullah S, Ahmed J, Wilson TR, McNaught C, et al. (2013) Influence of enhanced recovery after surgery pathways and laparoscopic surgery on health-related quality of life. Colorectal Dis 15(7): 900-907.

25. Watt DG, McSorley ST, Horgan PG, McMillan DC (2015) Enhanced Recovery After Surgery: Which Components, If Any, Impact on The Systemic Inflammatory Response Following Colorectal Surgery?: A Systematic Review. Medicine (Baltimore) 94(36): 1286.

\section{ISSN: 2574-1241}

DOI: 10.26717/BJSTR.2018.10.001894

Ana Belén Martínez Martínez. Biomed J Sci \& Tech Res

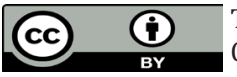

This work is licensed under Creative Commons Attribution 4.0 License

Submission Link: https://biomedres.us/submit-manuscript.php
26. Watt DG, Horgan PG, McMillan DC (2015) Routine clinical markers of the magnitude of the systemic inflammatory response after elective operation: a systematic review. Surgery 157(2): 362-380.

27. Ordemann J, Jacobi CA, Schwenk W, R Stösslein, JM Müller (2001) Cellular and humoral inflammatory response after laparoscopic and conventional colorectal resections. Surg Endosc 15(6): 600-608.

28. Crema E, Ribeiro EN, Hial AM, Alves Júnior JT, Pastore R, et al. (2005) Evaluation of the response of cortisol, corticotropin and blood platelets kinetics after laparoscopic and open cholecystectomy. Acta Cir Bras 20(5): 364-367.

29. Warschkow R, Steffen T, Beutner U, Müller SA, Schmied BM, et al. (2012) Diagnostic accuracy of $\mathrm{C}$-reactive protein and white blood cell counts in the early detection of inflammatory complications after open resection of colorectal cancer: a retrospective study of 1,187 patients. Int J Colorectal Dis 27(10): 1377.

30. Tsimogiannis KE, Telis K, Tselepis A, Pappas Gogos GK, Tsimoyiannis EC, et al. (2011) A-defensin expression of inflammatory response in open and laparoscopic colectomy for colorrectal cancer. World J Surg 35(8): 1911-1917.

31. Tsimogiannis KE, Tellis CC, Tselepis AD, Pappas Gogos GK, Tsimoyiannis EC, et al. (2012) Toll-like receptors in the inflammatory response during open and laparoscopic colectomy for colorectal cancer. Surg Endosc 26(2): 330-336.

32. Kobayashi E, Yoshida T, Yamauchi H, Yoshida T, Suminaga Y, et al. (1995) Immune function in patients undergoing open vs laparoscopic cholecystectomy. Arch Surg 130(6): 676.

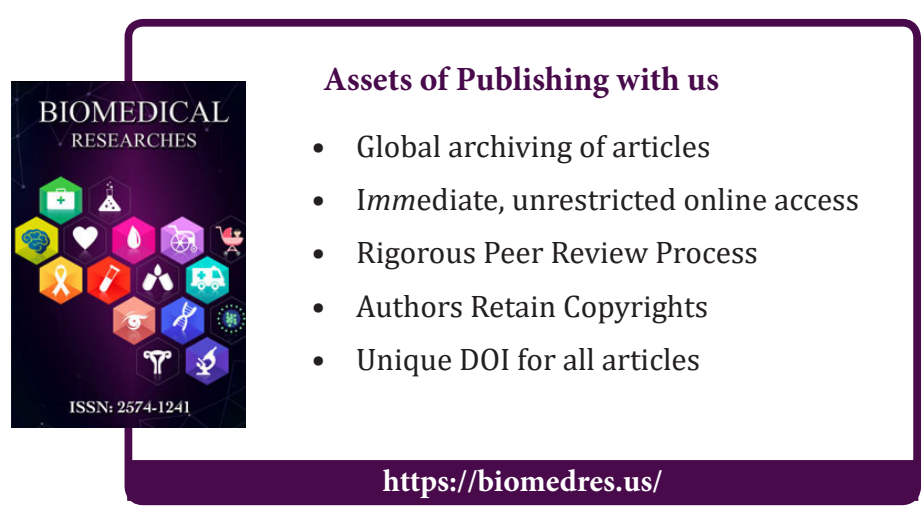

